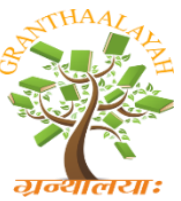

$$
\begin{gathered}
\text { INTERNATIONAL JOURNAL OF RESEARCH - } \\
\text { GRANTHAALAYAH } \\
\text { A knowledge Repository }
\end{gathered}
$$

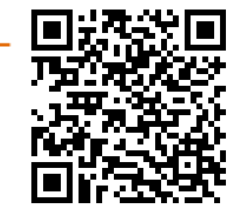

Science

\title{
PARAMETERS EVALUATION OF MUNICIPAL WASTE WATER AFTER TREATMENT USING SUB SURFACE FLOW CONSTRUCTED WETLAND IN EKANT PARK BHOPAL
}

\author{
Dr. Shalini Saxena *1 \\ ${ }^{* 1}$ Professor of Chemistry, Govt. M.L.B. College, Bhopal, India
}

DOI: https://doi.org/10.29121/granthaalayah.v4.i12.2016.2388

\begin{abstract}
Land areas which are wet during part or all of the year are referred as wetlands. Constructed wetlands are manmade systems that mimic the functions of natural wetlands and applied for wastewater treatment. Aim of the present study is to investigate the feasibility of using a Tracheophyte, Phragmites karka in constructed wetland for treatment of wastewater in an public park. The daily inlet and outlet wastewater physico-chemical parameters were analysed during the period of two months. The parameters studied were $\mathrm{pH}, \mathrm{BOD}, \mathrm{COD}, \mathrm{DO}$, Total Suspended Solids, Total Dissolved Solids, Nitrogen and Phosphorus. The percentage removal of the parameters were analysed and studied until the percent removal rate gets stabilized. The study showed that the subsurface flow constructed wetlands are best alternative among modern treatments.
\end{abstract}

Keywords: Constructed Wetlands; Phragmites Karka; Tracheophyte; Wastewater Treatment; Sub - Surface Wetlands.

Cite This Article: Dr. Shalini Saxena. (2016). "PARAMETERS EVALUATION OF MUNICIPAL WASTE WATER AFTER TREATMENT USING SUB SURFACE FLOW CONSTRUCTED WETLAND IN EKANT PARK BHOPAL." International Journal of Research - Granthaalayah, 4(12), 24-30. 10.29121/granthaalayah.v4.i12.2016.2388.

\section{Introduction}

Land areas that are wet during part or all of the year are referred as wetlands. These wetlands either natural or artificial (constructed) form, have a substantial capacity for wastewater treatment (Venus, 1987). Constructed wetlands are engineered systems that have been designed and constructed to utilise the natural processes involving wetland vegetation, soils and associated microbial assemblage to assist in treatment of wastewater. Constructed wetlands are based upon the symbiotic relationship between the microorganisms and pollutants in the wastewater (Stomp et al; 1994). Constructed wetlands have been used widely for the treatment of municipal, industrial and agricultural wastewater, as well as for urban rain water. This is owing to their high 
nutrient absorption capacity, simplicity, low construction, operation and maintenance costs, low energy demand, process stability, low excess sludge production and potential for creating biodiversity (Korkusuz et al., 2005). They are designed to take advantage of many of the processes that occur in natural wetlands, but do so within a more controlled manner. These systems can be used in almost in any environment for treatment of wastewater. Properly designed and constructed man-made wetland ecosystems are extremely efficient at utilizing and cleaning nutrient-rich waters (Mitsch and Gosselink, 1993). The constructed wetlands (CWs) for water pollution control are becoming an accepted technology worldwide. It is being used in many countries having arid or semiarid climates for removing particular contaminants from wastewaters. The Tracheophyte have capacity to improve the water quality by absorbing nutrients with their effective root system. Small communities in which the population is scattered over large land areas face problem for treating the wastewater mostly in case of the high per capita cost. To overcome this difficulty, small communities have to use natural systems for wastewater treatment because they are low in cost and do not require high technology to operate nor do they require highly trained person. Besides the low construction and operation maintenance expenditure and ease of operation, wetlands have positive effects on the public with their aesthetic value. Once constructed wetlands enhance flora and fauna, it becomes favourable habitat for birds. Also, these wetlands have negligible effects on air quality since polluted water circulates underground, preventing odour appearance. A constructed wetland can work efficiently for reducing Biochemical Oxygen Demand, Chemical Oxygen Demand, Total Potassium and Nitrogen, Total Suspended Solids and Total Coli forms (Gikas, 2007). These systems have potential to treat variety of wastewater by removing organics, suspended solids, pathogens, nutrients and heavy metals. The system does not require high level expenses, technical experts, expensive maintenance and has low environmental impacts (Yasar, 2007). The objective of the present study is to assess the wastewater quality performance in constructed pilot scale wetland system which examines the role of constructed wetlands in providing an efficient and economical means for treating wastewater. The study was carried out at Ekant Park Bhopal using a sewage which has previously undergone for primary treatment. A surface flow constructed wetland planted with Phragmites karka was constructed to treat the sewage. It was supposed that use of such water weed will reduce TSS, BOD and COD load in the sewage.

\section{Material and Methods}

Description of Site: The integrated constructed wetland unit combined with sub- surface flow and planted with Phragmites karka was built near sewage nala in Ekant park (Latitude 23.25' N, Longitude 77.40 S \& 523 meters above sea level). Madhya Pradesh is situated in central part of India. The climate of this region is tropical with an average annual rainfall of $1200 \mathrm{~mm}$. The mean minimum and maximum temperatures during the study period were $15^{\circ} \mathrm{C}$ and $40^{\circ} \mathrm{C}$ respectively.

Wetland Design: The integrated subsurface flow artificial wetland was constructed with cement $\&$ concrete of size $1.79 \mathrm{~m} \times 1.17 \mathrm{~m}$ having a depth of $0.36 \mathrm{~m}$. The tank is plastered in cement mortar on both sides. The bottom of the tank is made watertight. The necessary slope is provided at the bottom of the tank for sludge removal. The constructed wetland cell is of $2.16 \mathrm{~m}^{2}$ area and length to width ratio $1.79: 1.17$. The depth of the bed is $0.36 \mathrm{~m}$. The bed has regular rectangular shape and a necessary slope is provided at the bottom of the tank for sludge removal. The 
pretreatment plant chamber is also made of cement \& mortar of $0.6 \mathrm{mx} 0.6 \mathrm{~m}$ x $0.3 \mathrm{~m}$ \& volume $0.1 \mathrm{~m}$. ${ }^{3}$ The inlet pretreatment chamber \& the constructed wetland chamber are connected by underground PVC pipes of 2 inch diameter with a control valve. At the base of the wetland unit two pipes of 2 inch diameter having inward holes at every $5 \mathrm{~cm}$ distance run parallel in longitudinal direction from inlet chamber to outlet chamber to facilitate the drainage.

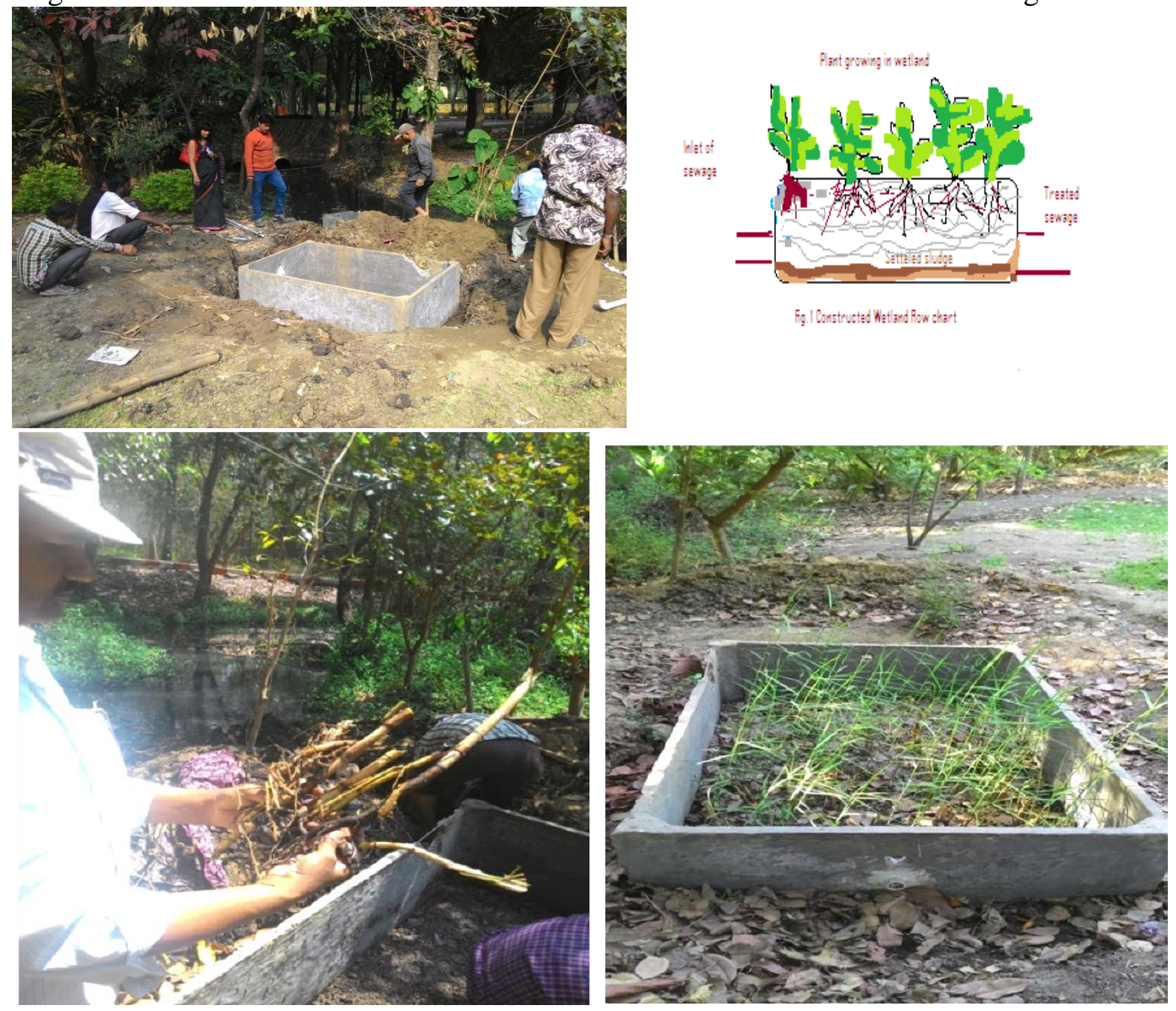

Wetland Vegetation: The study was carried out with Phragmites karka plants, which are grown in round shaped gravel filled in constructed wetlands. It was collected from local natural wetland and transplanted on the same day in a bucket filled with water and maintained for a period of 5 days to remove all previous impurities from the roots. These plants were transplanted from bucket to constructed wetland unit open to atmosphere in the park. The 5-6 cm spacing was set between the plants.

Operation and Monitoring: The nala wastewater was let into the constructed wetland intermittently over 30 days. The plants were monitored for general appearance, growth and health. The length of the plant was found to be similar to that of wetland plants in natural wetlands. Any invasive plants like ordinary grass were uprooted and removed immediately. The plant density spread vigorously within $4-6$ months. 
Sampling and Analysis: The study was performed in two sets A and B one for inlet water of the municipal nala \& other for the outlet water after 3 days retention time. The parameters analysed for the study were $\mathrm{pH}$, Dissolved Oxygen, Biochemical Oxygen Demand, Chemical Oxygen Demand, Total Suspended Solids, Total Dissolved Solids, Nitrogen and Phosphorus. Only quality of wastewater was analysed during the study period of 6 months i.e. October \& November. The sampling took place daily at both inlet and outlet of constructed wetland system. All the analysis was carried out as per standard methods for examination of wastewater

\section{Result \& Discussion}

\begin{tabular}{|l|l|l|l|}
\hline S.NO. & PARAMETERS & INLET SAMPLE & OUTLET SAMPLE \\
\hline 1. & Ph & 7.28 & 6.9 \\
\hline 2. & TSS & $15-20$ & $5-6$ \\
\hline 3. & TDS & 190 & 280 \\
\hline 4. & COD & $160-185$ & $19.2-38.40$ \\
\hline 5. & BOD & $122-150$ & $20-150$ \\
\hline 6. & DO & 3.4 & 7.1 \\
\hline 7. & Nitrate Nitrogen & 0.67 & 0.10 \\
\hline 8. & Nitrite Nitrogen & 0.29 & 0.90 \\
\hline 9. & Ammonia & 0.02 & 0.10 \\
\hline 10. & Phosphate Phosphorus & 0.53 & 0.31 \\
\hline 11. & Oil \& Grease & & Less than 2.0 \\
\hline
\end{tabular}

The overall system treatment performance was high and stable during the observation period. The method essentially consist of using wetland plants (Phragmites karka) to treat wastewater, the plants through their hollow stems ensure the presence of significant amount of air (O2) in the zone of their root systems, enabling development of aerobic bacterial colonies in the root zone. Bacteria use harmful matter from the wastewater for their nutrition. Part of this matter is used by plants for their growth. The concentrations of both influent and effluent from integrated constructed wetland system are displayed in Table.

$p H$

$\mathrm{pH}$ is the measurement of the intensity of acidity or alkalinity and measure the concentration of hydrogen ion in water. There is always continuous change between acidic and alkaline nature of the wastewater samples. The range of $\mathrm{pH}$ between 6.4 to 7.7 in the tank shows neutral nature of wastewater. The $\mathrm{pH}$ of inlet water was $7.28 \&$ after treatment it became 6.9

\section{Dissolved Oxygen}

The influent sample shows absence of dissolved oxygen before the treatment while after treatment the effluent showed increase in dissolved oxygen within the range of $3.4 \mathrm{mg} / \mathrm{l}$ to $7.1 \mathrm{mg} / \mathrm{l}$. This shows increasing range of dissolved oxygen in the effluent as compared to influent. The photosynthetic activities in plants increase the DO in water, thus creating aerobic conditions in the system which also favours the aerobic bacterial activity to reduce BOD. Improvement in DO signifies the efficient treatment level. 
Biochemical Oxygen Demand

It is the amount of oxygen that will be consumed by microorganisms during the biological reaction of oxygen with organic material. In the present study, it was observed that the influent BOD varies from $122 \mathrm{mg} / \mathrm{l}$ to $150 \mathrm{mg} / \mathrm{l}$ in Inlet Sample and $20.00 \mathrm{mg} / \mathrm{l}$ to $150 \mathrm{mg} / \mathrm{l}$ in Outlet Sample. The average percentage reduction is $86.19 \%$. These variations may be due to different bio-activity of microbes with temperature. In set $\mathrm{A}$, the metabolism and bio-activity of microbes were rather low whereas in set $\mathrm{B}$, with the increasing temperature, the biomasses and activities of microbes increased at high speed, which resulted in higher BOD5 removal (Steinmann et al., 2003). Because the process of anaerobic degradation requires a longer period of time for completion than aerobic decay, an anaerobic lagoon with approximately the same organic loading rate and detention time as an aerobic lagoon will not reduce the BOD5 as effectively.

\section{Chemical Oxidation Demand}

The COD of the inlet was $160-185 \mathrm{mg} / \mathrm{l}$ in and $19.2-38.40 \mathrm{mg} / \mathrm{l}$ in outlet water. Under the action of Phragmites karka the average reduction in COD is $87.5 \%$. The performance shows better result due to rise in temperature.

\section{Total Suspended Solids}

With low wetland water velocities and appropriate composition of influent solids, suspended solids will settle from the water column within the wetland. Sediment resuspension not only releases pollutants from the sediments, but also increases the turbidity and reduces light penetration. The mean value of Total Suspended Solids in influent wastewater ranges from in 15 $-20 \mathrm{mg} / \mathrm{l} \&$ in outlet sample B reduces to $5.00-6.00 \mathrm{mg} / \mathrm{l}$. The reduction in TSS is found to be $66 \%$. The percentage removal of TSS has reduced BOD load considerably. TSS mainly removed by physical process of sedimentation.

\section{Total Dissolved Solids}

The reductions in Total Dissolved Solids were very less. The result shows that percentage removal in TDS varies from $190 \mathrm{mg} / \mathrm{l}$ in inlet sample and $280.00 \mathrm{mg} / \mathrm{l}$ in outlet sample B showing increased percentage of TDS. This may be due to the pond acting as equalisation tank.

\section{Total Solids}

The Total solid was $205 \mathrm{mg} / \mathrm{l}$ in inlet sample \& $294.00 \mathrm{mg} / \mathrm{l}$ in outlet sample.

\section{Oil \& Grease}

Oil \& Grease becomes less than $2.00 \mathrm{mg} / \mathrm{l}$

\section{Total Nitrogen and Total Phosphorus}

Nitrogen and Phosphorus are very important polluting constituents of domestic wastewater because of their role in algal growth and eutrophication of water bodies. In sewage Nitrogen is present in the organic form. Organic nitrogen and ammonia nitrogen (NH3-N) are main nitrogen types in wastewater. Organic nitrogen is usually converted into NH3-N under both aerobic and anaerobic conditions. Therefore, NH3-N removal mainly contributed to total nitrogen (TN) removal. Three main processes involved in NH3-N removal were: hydrophytes uptake, volatilization and nitrification/denitrification (Sommer, 2000).Total Nitrogen is normally reduced by denitrification, adsorption and incorporation into cell mass (Al-Omari, 2003). Plants 
need Nitrogen for their growth and reproduction. They uptake nitrogen by their roots to incorporate it in the form of biomass (Baskar, 2009) It was also observed that the average Nitrogen as Nitrate in influent was $0.67 \mathrm{mg} / \mathrm{l}$. It was also observed that under the action of Phtagmites karka the total Nitrogen as nitrates is reduced to $0.10 \mathrm{mg} / \mathrm{l}$. Phosphorus is an important nutrient required for plant growth and is usually act as a limiting factor for vegetative productivity. Phosphorus is transformed in the wetland by a complicated biogeochemical cycle. The removal of phosphorus is important since it is known to be major limiting nutrient for algae growth in freshwater ecosystems (Wetzel, 2001). The major processes responsible for phosphorus removal in the constructed wetland are typically by adsorption, precipitation and plant up-take rates. The frequent filtration materials used in surface flow constructed wetland has a gravel base which is commonly good in absorption compared to the plant roots (Vymazal, 2004).Similarly, the average Phosphorus as phosphate as observed in the influent was $0.53 \mathrm{mg} / \mathrm{l}$. After treatment it gets reduced to $0.31 \mathrm{mg} / \mathrm{l}$ ). Nitrogen and Phosphorus removal efficiency was found less than $46 \%$.

\section{Conclusion}

The integrated constructed wetland system was observed to decrease effluents from Ekant Park municipal nalas, all the observed water quality parameters of the municipal wastewater, resulting in increasing water quality. The treated effluent values obtained were convenient with current Central Pollution Control Board regulations for domestic wastewater discharge. Implementing the constructed wetland technology is suitable for decentralised domestic wastewater treatment. This system is suitable as stand-alone treatment method for treating low middle strength wastewaters that show high variations in characteristics, especially originated from municipal nalas. The studied system proves to be best alternative to meet the prescribed standards of effluent which are set by Central Pollution Control Board. The Integrated sub surface flow constructed wetland system by using Phragmites karka seems to be viable alternative for reducing the organic matter content from municipal nalas. Applying the wastewater treatment system in public parks will support to enhance the environmental consciousness of the people besides being readily functional on educational purposes.

\section{Acknowledgement}

The authors wish to express thanks to CPA Officials, Ekant park Officials \& workers for providing land for constructing a constructed wetland. Sincere thanks are also to Dr. Billore, Dr. Nihal Singh \& Dr. Ram for their expert guidance \& the Department of Chemistry Govt. M. L. B. College Bhopal for providing facilities for research.

\section{References}

[1] Al -Omari, A. and M.Fayyad (2003) Treatment of domestic wastewater by subsurface flow constructed wetlands in Jordan. Desalination, 155, 27-39.

[2] APHA (1999), Standard Methods for Analysis of Water and Wastewater 19th ed.

[3] Baskar, G. (2009), "Treatment of wastewater from Kitchen in an Institution Hostel Mess using Constructed Wetland." International Journal of Recent Trends in engineering, Vol. 1, No. 6. 
[4] Bastviken, S. (2006). Nitrogen removal in treatment wetlands- Factors influencing spatial and temporal variations. Linkoping Studies in Science and Technology. Linkoping, Sweden, Linkoping University, Institute of Technology: 34.

[5] Choudhary M. (2007) "Water Hyacinth -A complete solution to wastewater treatment, Reclamation and Environment Protection" IE (I) Journal-EN.

[6] Gikas G., (2007) "Performance Monitoring Of A Vertical Flow Constructed Wetland Treating Municipal Wastewater" Global NEST Journal, Vol.9, No.3, pp 277-285.

[7] Indian Metrological Department, Kolhapur, India 10)Kadlec, H. and R.L.Knight; (1996) Treatment wetlands. CRC Press, Boca Ration, FL, USA.

[8] Korkusuz, E.A., Beklioglu, M. and Demirer, G.N. (2005): Comparison of the treatment performances of blast furnace slag-based and gravel-based vertical flow wetlands operated identically for domestic wastewater treatment in Turkey. Ecological Engineering, 24:187-200.

[9] Mitsch, W.J., Gosselink, J.G. (1993): Wetlands. 2nd ed., Van Nostrand Rheinhold, New York.

[10] Nikolic V., (2010), "Constructed Wetland Application in Wastewater Treatment Processes in Serbia.” BALWOIS 2010-Ohrid, Republic of Macedonia -25, 29 May 2010.

[11] Dhote S., Dixit S. (2007) Water Quality Improvement through Macrophytes: A Case Study, Asian J. Exp. Sci., Vol. 21, No. 2, 427- 430.

[12] Sommer, S.G., Olesen, J.E., (2000) Modelling ammonia volatilization from animal slurry applied with trail hoses to cereals. Atmospheric Environment, 34:2361-2372.

[13] Stomp,A.M., K.H.,Han, S.Wilbert, M.P.Gordonand S.D.Cunningham; (1994) Genetic strategies for enhancing phytoremediation, Ann. New York Acad. Sci. 721, 481-491.

[14] Steinmann, C.R., Weinhart, S., Melzer, A., (2003) A combined system of lagoon and constructed wetland for an effective wastewater treatment. Wat. Res., 37:2035-2042.

[15] Venus, G.C., (1987) Wetland wastewater treatment: A review. Whangarei, New Zealand.

[16] Vymazal, J. (2004): Removal of phosphorus in constructed wetlands with horizontal subsurface flow in the Czech Republic. Water, Air, and Soil Pollution, 4: 657-670.

[17] Wolverton, B. C., and R. C. McDonald. 1976. Water hyacinths for upgrading sewage lagoons to meet advanced wastewater standards: part II. NASA Technical Memorandum TM-X-72730 and 1978. Water hyacinth (Eichhornia crassipes) productivity and harvesting studies. NASA/ERL Report No. 171.

[18] Wolverton, B. C., and R. C. McDonald,1980,Comparative Study of Wastewater Lagoon with and without Water Hyacinth, Economic Botany, Vol. 34, No. 2 , pp. 101-110.

[19] Wetzel, R.G. (2001): Limnology-Lake and River Ecosystems, Academic Press, San Diego, CA.

[20] Yasar A., (2007), "Rehabilitation by constructed wetlands of available wastewater treatment plant in Salkhnin", Ecological Engineering, Vol.29, pp 27-32.

*Corresponding author.

E-mail address: drshalinisaxena@yahoo.com 